work on the rocks and minerals will. in conjunction with the field work, lead to a better understanding of the origin of the rocks and of some of the causes underlying the development of voleanic episodes in the region.

Work has begun with studies by Prof. Wager on the petrology and mineralogy of plutonic blocks ejected by the Soufriere Volcano, St. Vincent (1959 visit), and by P. E. Baker on the strato-volcano, Mt. Misery, on St. Kitts (1961 visit). Other students will begin work shortly on St. Lucia and Dominica, which are characterized by having centres of activity concentrated in almost circular caldera-type depressions, in which tholoids and ash deposits predominate and in which fumarole activity and earth tremors have persisted in recent years.

\section{Education by Television}

As a tool for instruction, television is accepted and well established in the United States. Television made its first appearance in education as long ago as 1932 at Iowa State University, but it was not until 1953 that it was first used for normal instruction. By 1960, half a million school-children and 100,000 college students were receiving regular instruction by television. This situation is in marked contrast with that prevailing in Great Britain. In a pamphlet entitled Educational Television : a Survey and a Plan, which has been published privately, John Wellens shows that in Britain educational television is practically synonymous with the schools television service run by both the B.B.C. and the independent network (Pp. $44+8$ plates. Guilsborough, near Northampton: John Wellens (ITT), Ltd., The Sun House, 1961. 5s.). The only exception consists of a handful of colleges and universities which have their own closed-circuit installations for giving instruction in special departments, such as medicine, dentistry and engineering. These installations are fow and have only recently been introduced; in many cases they have not yet developed beyond the pilot stage. In some cases the installations have been put in, below economic cost, to promote the acceptance of television as a teaching tool. Two Middlesex schools have been linked by micro-wave equipment for the teaching of chemistry, but, none the less, Britain is now at the stage reached by the Americans approximately ten years ago. Within the past year British educationists have become aware of the activity in this field in the United States and, in his booklet, Wellens describes the present position in the United States and makes a practical evaluation for Britain.

\section{Research Defence Society}

The Research Defence Society has published another of its pamphlets to make known the facts about experimental research involving the use of animals, and the conditions and regulations under which animal experiments are conducted in the United Kingdom. Animal Experiments in the Control of Animal Diseases is set out on the lines of previous pamphlets, that is, by posing a series of questions which the general public could rightly ask and by providing answers which are as objective and free from bias as humanly possible (Pp. 6. London: Research Defence Society, 1961. 6d.). In this new pamphlet the questions posed include: "Why are the treatment and prevention of animal disease important enough to warrant animal experiments? Why is animal experiment necessary to help in combating animal disease? Can you give examples of new agents for control of animal disease which would not have been developed without animal experiment? Can you explain the paradox that animal experiments involving suffering are used to prevent suffering in other animals? Why are animal tests necessary in the development of new drugs? How do animal experiments help in the control of animal disease ? Why are animal experiments necessary in the safety testing of vaccines for use in animals ?"

\section{The Museums Journal}

EarLIER this year it was decided to discontinue the monthly Museums Journal and publish instead a monthly Bulletin and a quarterly Journal. The first issue of the latter publication (No. 1; June 1961) was awaited with interest. The decision of the Council is fully justified, and curators are certainly not disappointed, for the new format even exceeds expectations. Mr. R. L. S. Bruce-Mitford describes the Book of Kells exhibition, stressing the technical presentation; Mr. Ronald Alley, in a comprehensive analysis, proves the almost total failure of British art galleries to acquire modern pictures and sculptures of foreign schools; and Mr. Stanley Rubenstein deals with the complicated problems of copyright. On the purely technical side, Mr. R. M. Organ gives a new treatment for 'bronze disease', and Mr. A. M. Tynan describes the uses of 'Styrocell'. Mr. Hugh Wakefield details the practical nature of the purchase grants made by the Victoria and Albert Museum. The issue also includes the annual report of the Museums Association for 1960-61, and a well-balanced Journal concludes with notes on the contributors and research work in progress.

\section{The Victorian American}

IN 1960 the family of the late Harry T. Peters presented the 'American on Stone' collection of lithographs to the Smithsonian Institution (Publication 4466: The Victorian American. By Antony N. B. Garvan and Peter C. Welsh. Lithographs from the Harry T. Peters 'American on Stone' Collection. Pp. 30. Washington, D.C.: Smithsonian Institution). The collection touches on every phase of American life in the nineteenth century. Part of this interesting material is now on tour as a travelling exhibition, and the 100 lithographs listed in a well-prepared catalogue include those illustrating technical progress, suburban novelty, rural nostalgia, the family and the genteel female, sports, fashion, the sea, politics, warfare and humour.

\section{Medical Research in East Africa}

A NEW treatment for tuberculosis and investigations into the causes of eye diseases in Africans are among the many items referred to in the report of the East African Council for Medical Research for 195960 (Pp. ii +15. Nairobi: Government Printer, 1960. 2s.). In tuberculosis, the important finding has been that thiacetazone (thiosemicarbazone), TB1, is as efficacious in combination with isonicotinis acid hydrazide (INAH) in therapy and in preventing drug resistance as is para-aminosalicylic acid (PAS). TB1 is cheap and palatable; PAS is expensive and patients dislike it. They are apt, therefore, to take INAH alone and thus acquire resistance to infections. A high (about 10 per cent) and increasing incidence of initial drug-resistance has been revealed in new and presumably untreated cases. The investigations now 